\title{
THERAPEUTIC TOUCH DAN TEKANAN DARAH PADA HIPERTENSI
}

\author{
Nailiy Huzaimah ${ }^{1}$, Iva Gamar Dian Pratiwi ${ }^{2}$ \\ ${ }^{1-2}$ Fakultas Ilmu Kesehatan, Universitas Wiraraja \\ Email: nailiy.huzaimah@wiraraja.ac.id
}

\begin{abstract}
ABSTRAK
Pengukuran tekanan darah merupakan suatu komponen penting dalam penatalaksanaan hipertensi. Secara umum penatalaksanaan hipertensi di Fasilitas Kesehatan Tingkat I di Indonesia masih berfokus pada edukasi perubahan pola hidup dan pemberian terapi farmakologi, belum menerapkan pemberian terapi komplementer untuk menunjang efektifitas terapi farmakologi. Therapeutic touch (TT) merupakan salah satu terapi komplementer jenis terapi energi yang telah dibuktikan memberikan pengaruh yang baik pada kesehatan. Tujuan penelitian ini adalah untuk menguji pengaruh pemberian TT terhadap tekanan darah sistolik (TDS) dan tekanan darah diastolik (TDD) penderita hipertensi. Jenis penelitian ini adalah eksperimen dengan desain pre-post test nonequivalent control group design. Responden penelitian adalah penderita hipertensi di Wilayah Kabupaten Sumenep yang memenuhi kriteria inklusi penelitian. Sampel didapatkan secara consecutive sampling $(\mathrm{n}=39)$, selanjutnya dibagi menjadi 2 kelompok, yaitu kelompok kontrol $(n=19)$ dan kelompok perlakuan (TT) $(n=20)$. Pengumpulan data dilakukan selama 3 hari pada siang dan malam hari yang meliputi pretest (T0) dan post-test (T1 dan T2). Uji T independen TDS siang T0 antara kelompok kontrol dan TT didapatkan nilai $\mathrm{p}=0,152$. Uji $\mathrm{T}$ independen dengan hasil signifikan $(\mathrm{p} \leq 0,05)$ ditemukan pada TDS malam T1 ( $\mathrm{p}=0,026)$, TDS siang T2 ( $\mathrm{p}=0,032)$, dan TDS malam T2 ( $\mathrm{p}=0,026)$. Hasil uji komparatif 2 kelompok berpasangan kelompok TT dengan menggunakan Paired T Test didapatkan nilai signifikan hanya pada perbandingan TDD malam T0 dan TDD malam T1 $(\mathrm{p}=0,022 \leq 0,05)$. Pada kelompok TT, rerata TDS siang T2 menurun dibandingkan TDS siang T1 $(\Delta=4,2 \mathrm{mmHg})$, rerata TDS malam T2 juga menurun dibandingkan TDS malam $\mathrm{T} 1(\Delta=0,45 \mathrm{mmHg})$. TT memberikan pengaruh penurunan TDS dan TDD pada hari diberikan intervensi (T1) dan hari berikutnya (T2), akan tetapi hasil statistik secara keseluruhan tidak signifikan kecuali pada perbandingan antara TDD malam T0 dan TDD malam T1. Penurunan tekanan darah setelah intervensi TT terjadi secara perlahan dan bertahap selama dua hari sejak diberi intervensi, tidak memberikan efek penurunan yang besar dan drastis.
\end{abstract}

Kata Kunci: therapeutic touch, terapi sentuh, tekanan darah, hipertensi, terapi energi

\section{ABSTRACT}

Blood pressure measurement is an important component in the management of hypertension. Management of hypertension in Primary Health Care in Indonesia still focuses on educating lifestyle changes and providing pharmacological therapy, has not implemented complementary therapy to support the effectiveness of the treatment. Therapeutic touch (TT) is a complementary type of energy therapy, which has been shown to have a good effect on health. The purpose of this study was to examine the effect of TT on systolic blood pressure (SBP) and diastolic blood pressure (DBP) in hypertensive patients. This study was an experimental study with a pre-posttest nonequivalent control group design. Respondents were hypertension patients in Sumenep Regency who met the inclusion criteria. Samples were obtained by consecutive sampling $(n=39)$, then divided into 2 groups, namely the control group $(n=19)$ and the treatment group $(n=20)$. Data collection was carried out for three days during the afternoon and night which included the pretest (TO) and posttest (T1 and T2). The results of the independent SBP afternoon TO between the control group and the TT obtained p- 
value $=0.152$. Independent $T$-test with significant results $(p \leq 0.05)$ was found on SBP night T1 ( $p=$ $0.026)$, day SBP T2 $(p=0.032)$, and SBP night T2 $(p=0.026)$. The results of the comparative test for the two groups paired with the TT group using the Paired T-test found a significant value only on the comparison of T0 nightly DBP and T1 nightly DBP $(p=0.022 \leq 0.05)$. In the TT group, the mean $S B P$ during the day $T 2$ decreased compared to the $S B P$ during the day $T 1(\triangle=4.2 \mathrm{mmHg})$, the mean $S B P$ at night T2 also decreased compared to the SBP at night $T 1(\Delta=0.45 \mathrm{mmHg})$. TT has the effect of decreasing SBP and DBP on the day of intervention (T1) and the next day (T2), but the overall statistical results are not significant except for the comparison between DBP at night TO and DBP at night T1. The decrease in blood pressure after TT intervention occurs slowly and gradually for 2 consecutive days since the intervention was given, meaning that it does not have a significant and drastic reduction effect on blood pressure.

Key Words: therapeutic touch, healing touch, blood pressure, hypertension, energy therapy 


\section{LATAR BELAKANG}

Hipertensi merupakan salah satu penyakit kardiovaskuler yang paling banyak terjadi di masyarakat dan menjadi pintu masuk atau faktor resiko penyakit kronik lain seperti gagal jantung, gagal ginjal, diabetes, dan stroke. Hasil Riskesdas Tahun 2018 didapatkan data diagnosis hipertensi menurut diagnosis dokter, diagnosis dokter atau minum obat, dan dari hasil pengukuran tekanan darah penduduk usia $\geq 18$ tahun berturut-turut yaitu mencapai 8,4\%, 8,8\%, dan 34,1\% (Kesehatan, 2018), artinya sekitar 1 dari 3 orang di Indonesia mengalami hipertensi. Pada umumnya penatalaksanaan hipertensi di Fasilitas Kesehatan Tingkat I hanya berfokus pada edukasi dan pemberian terapi farmakologi. Fasilitas kesehatan primer pada umumnya belum menerapkan pemberian terapi komplementer dan perawatan holistik untuk menunjang efektifitas terapi farmakologi dengan harapan terwujudnya kesehatan klien yang lebih optimal.

Therapeutic touch (TT) merupakan salah satu terapi komplementer jenis terapi energi yang selama beberapa dekade terakhir telah dibuktikan memberikan pengaruh yang signifikan pada kesehatan, salah satunya adalah membantu menurunkan nyeri seperti nyeri kepala, nyeri osteoartritis, nyeri post operasi, nyeri pada kanker, (Coakley \& Hospital, 2015; Gordon, Merenstein, D'Amico, \& Hudgens, 1998; Jackson et al., 2007; Keller \& Bzdek, 1986; Monroe, 2009; O'Mathúna, 2000). TT juga telah dibuktikan dapat menurunkan ansietas, meningkatkan kadar hemoglobin dan hematokrit, meningkatkan suhu tubuh bayi prematur, dan menurunkan suhu tubuh bayi yang hipertermia (Hanley, Coppa, \& Shields, 2017; Hikmah, Rustina, \& Pujasari, 2011; Movaffaghi, 2006; Ningsih, 2017; Pujiati, Hartini, \& Purnomo, 2017; Rosa, Rosa, Sarner, \& Barrett, 1998; Sayre-Adams, Wright, Biley, \& Richardson, 2001). Penelitian tentang efek pemberian TT terhadap penurunan tekanan darah pada penderita hipertensi masih terbatas di Indonesia. Penerapan TT pada penderita hipertensi pernah dilakukan di daerah Jepara dan memberikan efek yang baik berupa penurunan tekanan darah sistolik dan diastolik (Astuti \& Yulisetyaningrum, 2016).

Terapi TT didasarkan pada terapi pemulihan ketidakseimbangan energi. Penerapan TT yang terbukti memberi dampak baik pada kesehatan, tidak membutuhkan suatu alat yang spesifik, serta referensi yang masih terbatas tentang efek TT pada tekanan darah penderita hipertensi di area komunitas, maka tujuan penelitian ini adalah menguji pengaruh pemberian TT terhadap tekanan darah sistolik (TDS) dan tekanan darah diastolik (TDD) penderita hipertensi di komunitas.

\section{METODE PENELITIAN}

Penelitian eksperimen dengan rancangan pre and post test nonequivalent control group design ini telah disetujui oleh Komisi Etik Fakultas Keperawatan Universitas Airlangga (No: 2070-KEPK). Responden peneliltian ini berjumlah 39 orang . Responden dibagi menjadi dua kelompok yaitu kelompok perlakuan $(n=20)$ dan kelompok kontrol $(n=19)$. Penentuan responden dilakukan secara convenience sampling dengan kriteria inklusi: TDS $\geq 121 \mathrm{mmHg}$ atau TDD $\geq 81 \mathrm{mmHg}$ atau pernah mengalami sebelumnya TDS $\geq 121 \mathrm{mmHg}$ atau TDD $\geq 81$ $\mathrm{mmHg}$, tidak sedang menderita penyakit akut atau kronis lain yang parah atau secara signifikan mengganggu aktivitas sehari-hari, berusia 20 - 70 tahun, belum pernah mendapat intervensi TT sebelumnya. Pembagian sampel menjadi dua kelompok dilakukan secara nonrandom, yaitu dengan memenuhi sampel kelompok perlakuan terlebih dahulu, selanjutnya memenuhi sampel kelompok kontrol. Penelitian ini dilaksanakan di wilayah Kabupaten Sumenep meliputi Wilayah Puskesmas Pamolokan, Desa Kolor, Desa Patean, dan Desa Karang Anyar selama 10 bulan yaitu mulai bulan Maret - Agustus 2020. Alat dan bahan yang digunakan dalam penelitian ini adalah SOP pemberian TT, lembar observasi tekanan darah, spigmomanometer jarum, dan stetoscope. 
Responden dalam penelitian ini mengikuti prosedur penelitian dari awal hingga akhir yang dilakukan selama tiga hari berturut-turut. Pengukuran tekanan darah responden dilakukan pada dua waktu yaitu pada waktu sore (pukul 14.00 - 17.00) dan waktu malam (pukul 19.0021.00). Sesuai konsep teori irama sinkardian pada penderita hipertensi, waktu siang hingga sore adalah waktu puncak peningkatan tekanan darah sedangkan waktu malam adalah waktu puncak penurunan tekanan darah (Fabbian et al., 2013). Pada hari pertama (T0) dilakukan pengukuran tekanan darah pre-test (sistolik dan diastolik) di malam hari. Hari kedua (T1), dilakukan pengukuran tekanan darah pre test sesaat sebelum pemberian intervensi TT yaitu pada waktu sore (rentang pukul 14.00 - 17.00) dan dilanjutkan dengan post test sesaat setelah pemberian intervensi TT (masih dalam rentang pukul 14.00 - 17.00). Selanjutnya, pengukuran tekanan darah diukur kembali pada malam hari (pukul 19.00-21.00). Pada hari ketiga, dilakukan pengukuran tekanan darah sebagaimana pada hari pertama yaitu pada sore hari dan malam hari.

Pada kelompok perlakuan, pemberian intervensi TT dilakukan selama satu sesi, selanjutnya efek terhadap tekanan darah sistolik dan diastolik dievaluasi selama dua hari berturut-turut pada sore dan malam hari sesuai rentang waktu yang telah dijelaskan sebelumnya. Prosedur pemberian terapi TT menggunakan acuan Kriger, yaitu dengan meletakkan kedua telapak tangan terapis kurang lebih 2 hingga 4 inci (atau 5 hingga $10 \mathrm{~cm}$ ) dari permukaan tubuh responden, serta fokus merasakan energi responden. Penerapan TT terdiri dari lima fase yaitu pemusatan, pengkajian/penilaian, penjernihan/pembersihan, penyeimbangan, dan evaluasi. Terapi TT diberikan dalam waktu 15 - 20 menit pada masing-masing responden di waktu sore. Lama pemberian terapi bergantung pada intuisi terapis dalam merasakan dan mengevaluasi energi klien. Pada kelompok kontrol, responden tidak diberi intervensi apapun, hanya dilakukan pengukuran tekanan darah di waktu yang sama dengan kelompok perlakuan yaitu sore hari dan malam hari selama tiga hari berturut-turut. Data hasil penelitian selanjutnya dianalisis menggunakan Uji $\mathrm{T}$ independent dan Paired $\mathrm{T}$-test pada data yang berdistribusi normal, sedangkan pada data yang tidak berdistribusi normal menggunakan Uji Mann Whitney dan Wilcoxon Sign Rank. 


\section{HASIL DAN PEMBAHASAN}

Hasil penelitian menunjukkan mayoritas responden kelompok kontrol maupun kelompok perlakuan berjenis kelamin perempuan dan berada pada rentang usia 46 - 55 tahun. Pada kelompok perlakuan responden tidak bekerja sebanyak $60 \%$, sedangkan pada kelompok kontrol bekerja sebagai wiraswasta sebanyak 36,8\%. Tingkat pendidikan responden kelompok kontrol adalah SMA/sederajat sebanyak 45\%, sedangkan kelompok perlakuan adalah SD dan Sarjana masing-masing sebanyak 31,6\%. Profil demografi responden penelitian ini disajikan pada Tabel 1.

Tabel 1

Profil demografi responden

\begin{tabular}{|c|c|c|c|c|c|}
\hline \multirow[t]{2}{*}{ Karakteristik } & \multirow[t]{2}{*}{ Kategori } & \multicolumn{2}{|c|}{$\begin{array}{l}\text { Kelompok } \\
\text { Perlakuan }\end{array}$} & \multicolumn{2}{|c|}{$\begin{array}{c}\text { Kelompok } \\
\text { Kontrol }\end{array}$} \\
\hline & & $\mathbf{n}$ & $\%$ & $\mathbf{n}$ & $\%$ \\
\hline \multirow[t]{2}{*}{ Jenis kelamin } & Perempuan & 13 & 65 & 12 & 36,8 \\
\hline & Laki-laki & 7 & 35 & 7 & 63,2 \\
\hline \multirow{5}{*}{$\begin{array}{l}\text { Kelompok } \\
\text { usia }\end{array}$} & $17-25$ tahun & 1 & 5 & 1 & 5,3 \\
\hline & 26 - 35 tahun & 0 & 0 & 1 & 5,3 \\
\hline & 36 - 45 tahun & 5 & 25 & 7 & 36,8 \\
\hline & 46 - 55 tahun & 13 & 65 & 10 & 52,6 \\
\hline & $56-65$ tahun & 1 & 5 & 0 & 0 \\
\hline \multirow[t]{6}{*}{ Pekerjaan } & PNS & 5 & 25 & 3 & 15,8 \\
\hline & Petani & 0 & 0 & 1 & 5,3 \\
\hline & Wiraswasta & 3 & 15 & 7 & 36,8 \\
\hline & Buruh & 0 & 0 & 1 & 5,3 \\
\hline & Pemulung & 0 & 0 & 1 & 5,3 \\
\hline & Tidak bekerja & 12 & 60 & 0 & 0 \\
\hline \multirow{5}{*}{$\begin{array}{l}\text { Tingkat } \\
\text { Pendidikan }\end{array}$} & Tidak sekolah & 1 & 5 & 0 & 0 \\
\hline & $\mathrm{SD}$ & 1 & 5 & 6 & 31,6 \\
\hline & SMP/Sederajat & 1 & 5 & 3 & 15,8 \\
\hline & SMA/Sederajat & 9 & 45 & 4 & 21,1 \\
\hline & Sarjana & 8 & 40 & 6 & 31,6 \\
\hline
\end{tabular}

Hasil penelitian menunjukkan mayoritas responden pada kelompok perlakuan maupun kelompok kontrol berada pada stadium HT derajat II, memiliki riwayat keluarga hipertensi, dan tidak menggunakan terapi baik farmakologi maupun non-farmakologi. Riwayat kontrol atau berobat ke pelayanan kesehatan pada kelompok perlakuan sebanyak $65 \%$ berobat ke pelayanan kesehatan, sedangkan pada kelompok kontrol tidak berobat sebanyak 57,9\%. Data beban pikiran pada responden kelompok perlakuan adalah sebanyak $40 \%$ tidak ada beban pikiran, sedangkan pada kelompok kontrol sebanyak masing-masing 36,8\% mengatakan tidak ada beban pikiran dan sedang memiliki beban pikiran tingkatan berat.

Profil kesehatan responden penelitian ini disajikan pada Tabel 2 
Tabel 2

Data kesehatan responden

\begin{tabular}{|c|c|c|c|c|c|}
\hline \multirow[t]{2}{*}{ Karakteristik } & \multirow[t]{2}{*}{ Kategori } & \multicolumn{2}{|c|}{$\begin{array}{l}\text { Kelompok } \\
\text { Perlakuan }\end{array}$} & \multicolumn{2}{|c|}{$\begin{array}{c}\text { Kelompok } \\
\text { Kontrol }\end{array}$} \\
\hline & & $\mathbf{n}$ & $\%$ & $\mathbf{n}$ & $\%$ \\
\hline \multirow[t]{3}{*}{ Stadium HT } & $\begin{array}{l}\text { Peningkatan } \\
\text { tekanan } \\
\text { darah }\end{array}$ & 4 & 20 & 1 & 5,3 \\
\hline & HT derajat I & 7 & 35 & 5 & 26,3 \\
\hline & HT derajat II & 9 & 45 & 13 & 68,4 \\
\hline \multirow{2}{*}{$\begin{array}{l}\text { Riwayat } \\
\text { keluarga HT }\end{array}$} & Ya & 12 & 60 & 14 & 73,7 \\
\hline & Tidak & 8 & 40 & 5 & 26,3 \\
\hline \multirow{2}{*}{$\begin{array}{l}\text { Riwayat } \\
\text { Kontrol }\end{array}$} & $\mathrm{Ya}$ & 13 & 65 & 8 & 42,1 \\
\hline & Tidak & 7 & 35 & 11 & 57,9 \\
\hline \multirow[t]{3}{*}{$\begin{array}{l}\text { Penggunaan } \\
\text { terapi }\end{array}$} & $\begin{array}{l}\text { Farmokologi- } \\
\text { teratur }\end{array}$ & 7 & 35 & 5 & 26,3 \\
\hline & $\begin{array}{l}\text { Farmakologi- } \\
\text { tidak teratur }\end{array}$ & 3 & 15 & 4 & 21,1 \\
\hline & Tidak terapi & 10 & 50 & 10 & 52,6 \\
\hline \multirow[t]{4}{*}{ Beban pikiran } & Tidak ada & 8 & 40 & 7 & 36,8 \\
\hline & Ringan & 4 & 20 & 2 & 10,5 \\
\hline & Sedang & 4 & 20 & 3 & 15,8 \\
\hline & Berat & 4 & 20 & 7 & 36,8 \\
\hline
\end{tabular}

Dilakukan uji normalitas pada data tekanan darah kelompok perlakuan dan kontrol. Tabel 3 menunjukkan hasil uji normalitas data dengan menggunakan uji Kolmogorov-Smirnov.

Tabel 3

Hasil uji normalitas data dengan Kolmogorov-Smirnov

\begin{tabular}{lll}
\hline Karakteristik & Kelompok & Nilai P \\
\hline *Tekanan Darah Sistolik & Kontrol & $\mathbf{. 1 2 2}$ \\
\cline { 2 - 3 } Siang T0 & TT & $\mathbf{. 1 0 0}$ \\
\hline Tekanan Darah Diastolik & Kontrol & .009 \\
\cline { 2 - 3 } Siang T0 & TT & .118 \\
\hline Tekanan Darah Sistolik & Kontrol & .178 \\
\cline { 2 - 3 } Malam T0 & TT & .030 \\
\hline Tekanan Darah Diastolik & Kontrol & .003 \\
\cline { 2 - 3 } Malam T0 & TT & .200 \\
\hline Tekanan Darah Sistolik & Kontrol & .131 \\
\cline { 2 - 3 } Siang T1 & TT & .019 \\
\hline Tekanan Darah Diastolik & Kontrol & .018 \\
\cline { 2 - 3 } Siang T1 & TT & .033 \\
\hline *Tekanan Darah Sistolik & Kontrol & $\mathbf{. 2 0 0}$ \\
\cline { 2 - 3 } Malam T1 & TT & .012 \\
\hline Tekanan Darah Diastolik & Kontrol \\
\cline { 2 - 3 } Malam T1 & TT & .058 \\
\hline *Tekanan Darah Sistolik & Kontrol \\
\cline { 2 - 3 } Siang T2 & TT & $\mathbf{. 0 6 2}$ \\
\hline *Tekanan Darah Diastolik & Kontrol \\
\cline { 2 - 3 } Siang T2 & TT & $\mathbf{. 0 5 3}$ \\
\hline
\end{tabular}




\begin{tabular}{lll}
\hline Tekanan Darah Sistolik & Kontrol & .200 \\
\cline { 2 - 3 } Malam T2 & TT & .020 \\
\hline Tekanan Darah Diastolik & Kontrol & .048 \\
\cline { 2 - 3 } Malam T2 & TT & .058 \\
\hline
\end{tabular}

\section{Keterangan:}

* = data berdistribusi normal (memenuhi uji $\mathrm{T}$ )

T0 $=$ Hari sebelum pemberian intervensi atau perlakuan (untuk menentukan acuan

tekanan darah)

$\mathrm{T} 1=$ Hari pertama responden mendapatkan intervensi atau perlakuan

$\mathrm{T} 2=$ Hari kedua atau hari berikutnya setelah responden mendapatkan intervensi atau perlakuan

Berdasarkan Table 1, karakteristik yang kedua kelompok datanya berdistrisbusi normal adalah Tekanan Darah Sistolik Siang T0, Tekanan Darah Sistolik Malam T1, Tekanan Darah Sistolik Siang T2 dan Tekanan Darah Diastolik Siang T2 (P-value > 0.05). Hasil uji normalitas data Tabel 3 dilanjutkan dengan uji komparatif 2 kelompok independen yang disajikan pada Tabel 4 di bawah ini.

\section{Tabel 4}

\begin{tabular}{|c|c|c|c|c|}
\hline \multicolumn{5}{|c|}{ Hasil uji komparatif 2 kelompok independen } \\
\hline Variabel & $\begin{array}{c}\text { Kelompo } \\
\mathbf{k}\end{array}$ & Mean & Std. Deviation & P-Value \\
\hline \multirow{2}{*}{$\begin{array}{l}\text { Tekanan Darah Sistolik Siang } \\
\text { T0 }\end{array}$} & Kontrol & 149.37 & 24.304 & $0.152 *$ \\
\hline & TT & 139.75 & 16.124 & \\
\hline \multirow{2}{*}{$\begin{array}{l}\text { Tekanan Darah Diastolik Siang } \\
\text { T0 }\end{array}$} & Kontrol & 86.53 & 16.705 & $0.628 * *$ \\
\hline & TT & 82.70 & 14.618 & \\
\hline \multirow{2}{*}{$\begin{array}{l}\text { Tekanan Darah Sistolik Malam } \\
\text { T0 }\end{array}$} & Kontrol & 149.11 & 25.458 & $0.365^{* *}$ \\
\hline & $\mathrm{TT}$ & 143.50 & 26.524 & \\
\hline \multirow{2}{*}{$\begin{array}{l}\text { Tekanan Darah Diastolik } \\
\text { Malam T0 }\end{array}$} & Kontrol & 81.89 & 11.921 & $0.428 * *$ \\
\hline & TT & 86.70 & 20.212 & \\
\hline \multirow{2}{*}{$\begin{array}{l}\text { Tekanan Darah Sistolik Siang } \\
\text { T1 }\end{array}$} & Kontrol & 148.84 & 23.282 & $0.120 * *$ \\
\hline & TT & 138.10 & 21.401 & \\
\hline \multirow{2}{*}{$\begin{array}{l}\text { Tekanan Darah Diastolik Siang } \\
\text { T1 }\end{array}$} & Kontrol & 84.32 & 17.260 & $0.627 * *$ \\
\hline & $\mathrm{TT}$ & 83.85 & 15.003 & \\
\hline \multirow{2}{*}{$\begin{array}{l}\text { Tekanan Darah Sistolik Malam } \\
\text { T1 }\end{array}$} & Kontrol & 147.89 & 22.178 & $0.026^{*}$ \\
\hline & TT & 132.80 & 18.447 & \\
\hline \multirow{2}{*}{$\begin{array}{l}\text { Tekanan Darah Diastolik } \\
\text { Malam T1 }\end{array}$} & Kontrol & 85.95 & 15.750 & $0.166^{* * *}$ \\
\hline & TT & 79.50 & 18.931 & \\
\hline \multirow{2}{*}{$\begin{array}{l}\text { Tekanan Darah Sistolik Siang } \\
\text { T2 }\end{array}$} & Kontrol & 149.74 & 27.434 & $0.032 *$ \\
\hline & TT & 133.90 & 15.539 & \\
\hline \multirow{2}{*}{$\begin{array}{l}\text { Tekanan Darah Diastolik Siang } \\
\text { T2 }\end{array}$} & Kontrol & 83.32 & 17.920 & $0.974 *$ \\
\hline & TT & 83.15 & 13.616 & \\
\hline \multirow{2}{*}{$\begin{array}{l}\text { Tekanan Darah Sistolik Malam } \\
\text { T2 }\end{array}$} & Kontrol & 147.53 & 24.010 & $0.026 * *$ \\
\hline & $\mathrm{TT}$ & 132.35 & 15.222 & \\
\hline \multirow{2}{*}{$\begin{array}{l}\text { Tekanan Darah Diastolik } \\
\text { Malam T2 }\end{array}$} & Kontrol & 81.79 & 13.774 & $0.901 * *$ \\
\hline & TT & 83.55 & $\overline{15.602}$ & \\
\hline
\end{tabular}

*Uji T Independent

**Uji Mann Whitney

Tabel 4 menunjukan bahwa tidak ada perbedaan signifikan tekanan darah baik sistolik maupun diastolik, juga pada tekanan darah siang maupun malam antara kelompok kontrol 
dan kelompok TT pada pre-test atau T0 dengan rerata tekanan darah sistolik siang hari kelompok kontrol $149.37 \mathrm{mmHg}$ sedangkan kelompok TT $139.75 \mathrm{mmHg}$ dan rerata tekanan darah sistolik malam hari kelompok kontrol $149.11 \mathrm{mmHg}$ sedangkan kelompok TT 143.50 mmHg. Tidak ada perbedaan yang signifikan pula pada tekanan darah sistolik maupun diastolik sesaat sebelum pemberian intervensi TT dan sesaat setelah pemberian intervensi TT antara kelompok kontrol dan kelompok TT pada post-test sore T1 . Perbedaan yang signifikan terjadi pada tekanan darah sistolik post test malam T1 antara kelompok kontrol dan kelompok TT. Perbedaan yang signifikan juga terjadi pada tekanan darah sistolik post test siang T2 dan tekanan darah sistolik post test malam T2 antara kelompok kontrol dan kelompok TT. Tidak ditemukan perbedaan yang signifikan pada tekanan darah diastolik post test baik pada waktu sore maupun malam hari dan pada T1 maupun T2.

Analisis data dilanjutkan dengan uji komparatif dua kelompok berpasangan pada kelompok kontrol dan kelompok perlakuan. Uji berpasangan pada kelompok kontrol disajikan pada Tabel 5, sedangkan uji berpasangan pada kelompok perlakuan disajikan pada Tabel 6.

Tabel 5

Uji berpasangan pada kelompok kontrol

\begin{tabular}{|c|c|c|c|c|c|}
\hline \multicolumn{2}{|c|}{ Karakteristik } & Mean & Std. Deviation & Std. Error Mean & P-Value \\
\hline \multirow[t]{2}{*}{ Pair 1} & Sistolik Siang T0 & 149.37 & 24.304 & 5.576 & $0.854 *$ \\
\hline & Sistolik Siang T1 & 148.84 & 23.282 & 5.341 & \\
\hline \multirow[t]{2}{*}{ Pair 2} & Diastolik Siang T0 & 86.53 & 16.705 & 3.832 & $0.229 * *$ \\
\hline & Diastolik Siang T1 & 84.32 & 17.260 & 3.960 & \\
\hline \multirow[t]{2}{*}{ Pair 3} & Sistolik Siang T0 & 149.37 & 24.304 & 5.576 & $0.888 *$ \\
\hline & Sistolik Siang T2 & 149.74 & 27.434 & 6.294 & \\
\hline \multirow[t]{2}{*}{ Pair 4} & Diastolik Siang T0 & 86.53 & 16.705 & 3.832 & $0.21 * *$ \\
\hline & Diastolik Siang T2 & 83.32 & 17.920 & 4.111 & \\
\hline \multirow[t]{2}{*}{ Pair 5} & Sistolik Siang T1 & 148.84 & 23.282 & 5.341 & $0.782 *$ \\
\hline & Sistolik Siang T2 & 149.74 & 27.434 & 6.294 & \\
\hline \multirow[t]{2}{*}{ Pair 6} & Diastolik Siang T1 & 84.32 & 17.260 & 3.960 & $0.457^{* *}$ \\
\hline & Diastolik Siang T2 & 83.32 & 17.920 & 4.111 & \\
\hline \multirow[t]{2}{*}{ Pair 7} & Sistolik Malam T0 & 149.11 & 25.458 & 5.840 & $0.669 *$ \\
\hline & Sistolik Malam T1 & 147.89 & 22.178 & 5.088 & \\
\hline \multirow[t]{2}{*}{ Pair 8} & Diastolik Malam T0 & 81.89 & 11.921 & 2.735 & $0.2 * *$ \\
\hline & Diastolik Malam T1 & 85.95 & 15.750 & 3.613 & \\
\hline \multirow[t]{2}{*}{ Pair 9} & Sistolik Malam T0 & 149.11 & 25.458 & 5.840 & $0.622 *$ \\
\hline & Sistolik Malam T2 & 147.53 & 24.010 & 5.508 & \\
\hline \multirow[t]{2}{*}{ Pair 10} & Diastolik Malam T0 & 81.89 & 11.921 & 2.735 & $0.886^{* * *}$ \\
\hline & Diastolik Malam T2 & 81.79 & 13.774 & 3.160 & \\
\hline \multirow[t]{2}{*}{ Pair 11} & Sistolik Malam T1 & 147.89 & 22.178 & 5.088 & $0.897 *$ \\
\hline & Sistolik Malam T2 & 147.53 & 24.010 & 5.508 & \\
\hline \multirow[t]{2}{*}{ Pair 12} & Diastolik Malam T1 & 85.95 & 15.750 & 3.613 & $0.128 * *$ \\
\hline & Diastolik Malam T2 & 81.79 & 13.774 & 3.160 & \\
\hline
\end{tabular}

*Uji Paired T Test

**Uji Wilcoxon

Uji berpasangan pada kelompok kontrol menunjukkan terjadi penurunan rerata tekanan darah sistolik siang hari antara T0 $(149,37 \mathrm{mmHg})$ dan $\mathrm{T} 1(148,84)$ sebesar 0,53 $\mathrm{mmHg}$. Penurunan rerata tekanan darah sistolik juga terjadi pada malam hari antara T0 (149 $\mathrm{mmHg})$ dan $\mathrm{T} 1(147,89)$ sebesar $1,22 \mathrm{mmHg}$, antara T0 $(149 \mathrm{mmHg})$ dan T2 $(147,53 \mathrm{mmHg})$ sebesar 1,58 $\mathrm{mmHg}$, dan antara $\mathrm{T} 1(147,89 \mathrm{mmHg})$ dan $\mathrm{T} 2(147,53 \mathrm{mmHg})$ sebesar 0,36 mmHg. Terjadi peningkatan pada rerata tekanan darah sistolik siang hari antara T0 $(149,37$ 
$\mathrm{mmHg})$ dan $\mathrm{T} 2(149,74 \mathrm{mmHg})$ sebesar $0,37 \mathrm{mmHg}$, antara $\mathrm{T} 1(148,84 \mathrm{mmHg})$ dan $\mathrm{T} 2$ $(149,74 \mathrm{mmHg})$ sebesar $0,9 \mathrm{mmHg}$. Rerata tekanan darah diastolik baik siang maupun malam hari secara keseluruhan menunjukkan terjadi penurunan, kecuali pada rerata tekanan darah diastolik malam hari antara $\mathrm{T} 0(81,89 \mathrm{mmHg})$ dan $\mathrm{T} 1(85,95 \mathrm{mmHg})$ sebesar 4,06 $\mathrm{mmHg}$. Hasil uji berpasangan dengan paired t-test dan Wilcoxon Signed Rank Test seluruhnya menunjukkan $p$-value $\geq 0,05$, menunjukkan tidak terjadi perbedaan secara signifikan antara tekanan darah sistolik maupun diastolik, siang hari maupun malam hari pada kelompok kontrol di antara T0 dan T1, T0 dan T2, serta T1 dan T2.

Tabel 6

Uji berpasangan pada kelompok perlakuan (TT)

\begin{tabular}{|c|c|c|c|c|c|}
\hline & & Mean & Std. Deviation & Std. Error Mean & P-Value \\
\hline \multirow[t]{2}{*}{ Pair 1} & $\begin{array}{l}\text { Sistolik Siang T0 } \\
\end{array}$ & 139.75 & 16.124 & 3.605 & $0.977 * *$ \\
\hline & Sistolik Siang T1 & 138.10 & 21.401 & 4.785 & \\
\hline \multirow[t]{2}{*}{ Pair 2} & Diastolik Siang T0 & 82.70 & 14.618 & 3.269 & $0.624 *$ \\
\hline & Diastolik Siang T1 & 83.85 & 15.003 & 3.355 & \\
\hline \multirow[t]{2}{*}{ Pair 3} & Sistolik Siang T0 & 139.75 & 16.124 & 3.605 & $0.628 * *$ \\
\hline & Sistolik Siang T2 & 133.90 & 15.539 & 3.475 & \\
\hline \multirow[t]{2}{*}{ Pair 4} & Diastolik Siang T0 & 82.70 & 14.618 & 3.269 & $0.21 * *$ \\
\hline & Diastolik Siang T2 & 83.15 & 13.616 & 3.045 & \\
\hline \multirow[t]{2}{*}{ Pair 5} & Sistolik Siang T1 & 138.10 & 21.401 & 4.785 & $0.909 * *$ \\
\hline & Sistolik Siang T2 & 133.90 & 15.539 & 3.475 & \\
\hline \multirow[t]{2}{*}{ Pair 6} & Diastolik Siang T1 & 83.85 & 15.003 & 3.355 & $0.457 * *$ \\
\hline & Diastolik Siang T2 & 83.15 & 15.602 & 3.489 & \\
\hline \multirow[t]{2}{*}{ Pair 7} & Sistolik Malam T0 & 143.50 & 26.524 & 5.931 & $0.669 * *$ \\
\hline & Sistolik Malam T1 & 132.80 & 18.447 & 4.125 & \\
\hline \multirow[t]{2}{*}{ Pair 8} & Diastolik Malam T0 & 86.70 & 20.212 & 4.520 & $0.022 *$ \\
\hline & Diastolik Malam T1 & 79.50 & 18.931 & 4.233 & \\
\hline \multirow[t]{2}{*}{ Pair 9} & Sistolik Malam T0 & 143.50 & 26.524 & 5.931 & $0.457 * *$ \\
\hline & Sistolik Malam T2 & 132.35 & 15.222 & 3.404 & \\
\hline \multirow[t]{2}{*}{ Pair 10} & Diastolik Malam T0 & 86.70 & 20.212 & 4.520 & $0.463 *$ \\
\hline & Diastolik Malam T2 & 83.55 & 15.602 & 3.489 & \\
\hline \multirow[t]{2}{*}{ Pair 11} & Sistolik Malam T1 & 132.80 & 18.447 & 4.125 & $0.917 * *$ \\
\hline & Sistolik Malam T2 & 132.35 & 15.222 & 3.404 & \\
\hline \multirow[t]{2}{*}{ Pair 12} & Diastolik Malam T1 & 79.50 & 18.931 & 4.233 & $0.370 *$ \\
\hline & Diastolik Malam T2 & 83.55 & 15.602 & 3.489 & \\
\hline
\end{tabular}

*Uji Paired T Test

**Uji Wilcoxon

Uji berpasangan pada kelompok perlakuan menunjukkan secara keseluruhan terjadi penurunan rerata tekanan darah sistolik pada siang hari maupun malam hari. Rerata penurunan tekanan darah sistolik paling tinggi terjadi pada perbandingan antara tekanan darah sistolik malam hari T0 dan T2 yaitu sebesar 11,15 mmHg. Rerata tekanan darah diastolik menurun pada perbandingan antara tekanan darah diastolik siang T1 dan T2 $(0,7$ $\mathrm{mmHg})$, tekanan darah diastolik malam $\mathrm{T} 0$ dan $\mathrm{T} 1(7,2 \mathrm{mmHg})$, dan antara tekanan darah diastolik malam T0 dan T2 $(3,15 \mathrm{mmHg})$. Rerata tekanan darah diastolik mengalami

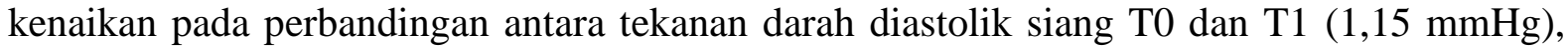
tekanan darah diastolik siang $\mathrm{T} 0$ dan $\mathrm{T} 2(0,45 \mathrm{mmHg})$, dan antara tekanan darah diastolik malam T1 dan T2 (4,05 mmHg). Pengujian Paired T-Test yang menunjukkan perbedaan signifikan pada kelompok perlakuan hanya terjadi pada perbandingan tekanan darah diastolik malam hari antara T0 dan T1 dengan nilai $p$-value $(0,022) \leq 0,05$, sedangkan yang lainnya didapatkan nilai $p$-value $\geq 0,05$. 
Hasil penelitian ini menunjukkan tidak ada perbedaan signifikan tekanan darah baik sistolik maupun diastolik pada siang maupun malam hari antara kelompok kontrol dan kelompok TT pada pre-test atau T0. Artinya bahwa data tekanan darah yang didapatkan pada T0 sebagai acuan dasar (base line) tekanan darah antara kelompok kontrol dan kelompok TT tidak ada perbedaan. Rerata tekanan darah sistolik (TDS) siang hari kelompok kontrol 149.37 mmHg sedangkan kelompok TT $139.75 \mathrm{mmHg}$ dan rerata tekanan darah sistolik (TDS) malam hari kelompok kontrol $149.11 \mathrm{mmHg}$ sedangkan kelompok TT $143.50 \mathrm{mmHg}$. Tidak ada perbedaan yang signifikan pula antara TDS dan tekanan darah diastolik (TDD) sesaat sebelum pemberian intervensi TT (pre-test siang T0) dengan sesaat setelah pemberian intervensi TT (post-test siang T1) antara kelompok kontrol dan kelompok TT. Hasil ini menunjukkan bahwa tidak ada perbedaan signifikan TDS maupun TDD sesaat setelah pemberian intervensi TT (post-test siang T1) antara kelompok kontrol dan kelompok TT. Belum ada penelitian sebelumnya yang membahas tentang hasil uji komparatif dua kelompok independen TDS danTDD antara kelompok kontrol dan kelompok TT, sehingga belum ada pembanding hasil penelitian ini dengan penelitian sebelumnya tentang perbandingan TDS dan TDD post test sesaat setelah pemberian intervensi antara kelompok kontrol dan kelompok TT.

Perbedaan yang signifikan terjadi pada TDS post-test malam T1, TDS post test siang T2, dan TDS post test malam T2 antara kelompok kontrol dan kelompok TT.. Hasil ini menunjukkan bahwa terjadi perubahan tekanan darah yang signifikan pada TDS post-test malam T1, TDS post test siang T2, dan TDS post test malam T2 dibandingkan TDS pre-test siang maupun malam T0 dan TDS post-test siang T1. Tidak ada perbedaan yang signifikan pada TDD post test baik pada waktu sore maupun malam hari dan pada T1 maupun T2 antara kelompok kontrol dan kelompok TT.

Hasil uji berpasangan kelompok TT, didapatkan perbedaan yang signifikan hanya pada perbandingan antara TDD pre-test malam T0 dengan TDD post-test malam T1. Rerata TDS malam T1 menurun dengan rerata penurunan 10,7 mmHg. Hasil ini berarti bahwa TT memberi efek lanjutan terhadap tekanan darah beberapa jam setelah intervensi, yaitu pada malam hari setelah di sore harinya diberi intervensi TT. Rerata TDS siang T2 juga menurun dibandingkan TDS siang T1 dengan penurunan sebesar $4,2 \mathrm{mmHg}$, selanjutnya rerata TDS malam T2 juga menurun dibandingkan TDS malam T1 dengan penurunan sebesar 0,45 mmHg. Konsep irama sinkardian tekanan darah pada penderita hipertensi, waktu siang hingga sore adalah waktu puncak tekanan darah sedangkan waktu malam adalah waktu puncak penurunan tekanan darah (Fabbian et al., 2013). Hasil penelitian ini memberikan hasil yang berbeda dengan konsep yang ditemukan oleh Fabbianet, yaitu pada kelompok TT, rerata TDS siang pretest (T0) lebih rendah $(139,75 \mathrm{mmHg})$ dibandingkan TDS malam pretest (T0) (143,50 mmHg). Akan tetapi pada T1 dan T2 (post-test) hasilnya sesuai dengan konsep yang dikemukaan oleh Fabbianet dari hasil peneliltiannya, yaitu rerata TDS siang lebih tinggi dibandingkan rerata TDS malam.

Hasil penelitian sebelumnya pada uji berpasangan kelompok TT yaitu antara pre-test (sebelum diberi intervensi TT) dan post-test (setelah diberi intervensi TT), banyak memberikan hasil yang sama seperti hasil penelitian ini, yaitu terjadi penurunan baik TDS maupun TDD setelah pemberian intervensi TT, akan tetapi secara statistik tidak signifikan. Penelitian yang dilakukan pada penderita post operasi bedah $(n=81)$ di Unit Rawat Jalan Pusat Layanan Kesehatan St. Luke's Wood River, Amerika Serikat dengan metode studi percontohan secara acak (randomized pilot study) ditemukan tidak ada perbedaan tekanan darah yang signifikan antara sebelum dan setelah pemberian terapi sentuh (TT) baik sistolik maupun diastolik. Intinya, pemberian terapi sentuh tidak memberikan efek yang signifikan terhadap penurunan tekanan darah sistolik dan diastolik dengan metode pengukuran tekanan 
darah dilakukan sesaat (pada saat itu juga) setelah intervensi. Pada penelitian ini, TT lebih memberikan efek yang signifikan pada nyeri dan ansietas (Foley, Anderson, Mallea, Morrison, \& Downey, 2016). Berbeda dengan hasil penelitian yang dilakukan di daerah Jepara-Indonesia di area komunitas didapatkan hasil yaitu pemberian terapi sentuh (healing touch) memberikan pengaruh yang signifikan pada tekanan darah $(\mathrm{p}=0,000)$, dimana pada penelitian ini tekanan darah post-test diukur langsung sesaat setelah pemberian terapi (Astuti \& Yulisetyaningrum, 2016).

Penelitian sebelumnya yang dilakukan di Ruang ICU Rumah Sakit Pendidikan Ayatollah Mousavi dan Valiasr Iran menunjukkan bahwa TT menurunkan TDS dimana paling signifikan terjadi penurunan setelah menjalani sesi ke 4 (hari ke-4) dengan penurunan TDS sebesar 3,37 mmHg antara sebelum dan setelah perlakuan pada hari ke-4 ( $p$-value = 0,005) (Zaeimi, Ramazani-Badr, \& Bahrami, 2017). Penelitian yang dilakukan di Pusat Nyeri dan Penanganan Stres di Gedung Keperawatan Universitas Southern Maine Amerika Serikat menunjukkan tekanan darah individu yang diterapi TT mengalami penurunan setelah pemberian TT dengan rentang rerata penurunan tekanan darah sistolik adalah 4,4 - 14,6 $\mathrm{mmHg}$ pada sesi 2 hingga sesi 8 pemberian TT. Tekanan darah diastolik menunjukkan penurunan yang tidak signifikan pada keseluruhan sesi selama 8 minggu (Smith \& Broida, 2007).

Pemberian TT juga dilakukan pada pasien yang sedang menjalani biopsi payudara inti stereotaktik. Terjadi penurunan tekanan darah sistolik dan diastolik setelah pemberian TT. Penurunan tekanan darah sistolik dan diastolik lebih besar pada kelompok TT ( $\triangle \mathrm{TDS}=3,2$ $\mathrm{mmHg}$ dan $\triangle \mathrm{TDD}=1,3 \mathrm{mmHg}$ ) dibandingkan plasebo (tindakan menyerupai $\mathrm{TT})(\triangle \mathrm{TDS}=$ $2,1 \mathrm{mmHg}$ dan $\triangle \mathrm{TDD}=0,4 \mathrm{mmHg}$ ), namun hasil uji statistik tidak signifikan $(\mathrm{p} \geq 0,05)$ (Jackson et al., 2007). Penelitian pada 38 wanita dan 115 pria yang sedang menunggu operasi jantung terbuka di hari berikutnya (sebagai pasien) di rumah sakit kecil pusat kesehatan swasta di Carolina Selatan, ditemukan bahwa TDS dan TDD mengalami penurunan paling besar pada kelompok TT dibandingkan dengan kelompok yang mendapatkan perlakuan tindakan menyerupai TT dan kelompok kontrol ( $\triangle$ TDS kelompok TT=4,32 $\mathrm{mmHg}$ dan $\Delta \mathrm{TDD}=1,88 \mathrm{mmHg}$ ) (Quinn, 1984). Penelitian pada 53 individu di ruang CCU Rumah Sakit Umum Daerah di London ditemukan tidak ada perbedaan yang signifikan pada variabel fisiologis antara pra, intra, dan pasca pemberian TT. Mean Arterial Pressure (MAP) menurun selama pemberian TT (rerata MAP $=96,1$ ), dan menjadi meningkat setelah pemberian TT (rerata $\mathrm{MAP}=98,3 \mathrm{mmHg})(\mathrm{p}=0,6)$. Penelitian ini menyebutkan bahwa TT lebih memberikan efek pada respon psikodinamik dibandingkan respon fisiologis (C. Cox \& Hayes, 1999).

TT didefinisikan sebagai pendekatan holistik untuk mengatur, meningkatkan, menyeimbangkan, dan melindungi energi dengan mempengaruhi medan energi dengan tangan untuk menyembuhkan penyakit atau gejala akibat ketidakseimbangan medan energi. Tujuan utama TT adalah memperdalam kesadaran dan menyeimbangkan energi. TT dikenal untuk melengkapi terapi lain dan intervensi medis, merupakan metode non-farmakologis, non-invasif, mudah, murah, dan aman di mana praktisi mentransfer energi ke pasien melalui tangannya. Sentuhan terapeutik adalah dikenal untuk melengkapi terapi lain dan intervensi medis (Turan, 2015; Mathuna \& Ashford, 2014; Cookley \& Duffy, 2010; Cox \& Hayes, 1997).

Hasil penelitian ini didapatkan pola perubahan tekanan darah yang beragam setelah pemberian TT. Sejumlah 9 responden (45\%) pada penelitian ini mengalami kenaikan TDS pada T1, yaitu pengukuran tekanan darah sesaat setelah pemberian TT. Selanjutnya, TDS 7 
responden berangsur turun pada $\mathrm{T} 1$ dan $\mathrm{T} 2$, baik hasil pengukuran siang maupun malam hari. Dua responden memberikan pola yang berbeda, yaitu mengalami kenaikan tekanan darah bahkan secara berangsur pada T1 hingga T2. Pada responden ke-6 peningkatan tekanan darah mungkin berhubungan dengan nyeri kepala skala 4 (rentang nyeri skala 0-10) yang saat itu sedang dirasakan, juga adanya beban pikiran yang menurut responden pada kategori beban pikiran berat. TDS siang responden ke-6 pada pretest T0, post test T1, dan post-test T2 pada siang hari secara berurutan adalah 120, 130, dan $140 \mathrm{mmHg}$. Pada responden lainnya yaitu responden ke-4 dengan TDS siang pre-test T0 $110 \mathrm{mmHg}$, dengan riwayat hipertensi, mengalami kenaikan tekanan darah secara berangsur pada post test siang T1 dan T2 secara berurutan yaitu 118 dan $120 \mathrm{mmHg}$. Hal ini menunjukkan bahwa TT tidak selalu memberi efek penurunan tekanan darah pada penderita hipertensi. Responden ke-4 yang mengalami penurunan tekanan darah pada saat penelitian, setelah diberi intervensi TT mengalami kenaikan tekan darah secara bertahap, dimana mencapai angka $120 \mathrm{mmHg}$ di post test hari ke-2 yaitu pada $\mathrm{T} 2$.

Thetapeutic touch (TT) didefinisikan sebagai pendekatan holistik untuk mengatur, meningkatkan, menyeimbangkan, dan melindungi energi dengan mempengaruhi medan energi dengan tangan untuk menyembuhkan penyakit atau gejala akibat ketidakseimbangan medan energi. Tujuan utama TT adalah memperdalam kesadaran dan menyeimbangkan energi. TT adalah sebuah metode non-farmakologis, non-invasif, mudah, murah, dan aman di mana praktisi mentransfer energi ke pasien melalui tangannya. TT dikenal untuk melengkapi terapi lain dan intervensi medis (Bulette Coakley \& Duffy, 2010; C. L. Cox \& Hayes, 1997; O’Mathúna, 2016; Turan, 2015). Menurut Krieger, efek utama dari TT adalah pada sistem saraf otonom dengan cara meningkatkan kekuatan sistem saraf parasimpatis dan mengurangi aktivitas sistem saraf simpatis (Matourypour et al., 2016). Krieger menggambarkan perubahan ini sebagai respons ketenangan cepat yang biasanya dibuat pada menit pertama akibat aktivasi sistem saraf otonom, dan ditandai dengan penurunan tekanan darah, penurunan laju pernapasan, penurunan denyut nadi, dan rileks sistem saraf tepi. TT memicu pelepasan enkephalin dan hormon endogen dan sebagainya itu mengurangi rasa sakit dengan berperilaku seperti morfin (Cai \& Zhang, 2015), sehingga melalui jalur ini pula pemberian TT akan memberikan efek pada tekanan darah. TT direkomendasikan sebagai metode yang memiliki ekstensi berpotensi untuk menimbulkan relaksasi fisiologis pada pasien (C. L. Cox \& Hayes, 1997). Teknik ini adalah seni perawatan konsentrasi dimana terapis menggunakan tangannya dengan memusatkan perhatian pada kesadaran sebagai fokus untuk menciptakan keseimbangan dan koordinasi dalam bidang energi timbal balik antara pasien dan lingkungan (Matourypour et al., 2016). Belum ditemukan kekurangan atau dampak negatif pemberian TT kepada pasien (Monroe, 2009).

Efek penurunan tekanan darah yang dialami oleh responden penelitian ini kemungkinan melalui jalur saraf maupun hormonal yang telah diungkapkan oleh Krieger dan Cai \& Zhang sebelumnya. Respon fisiologis masing-masing individu setelah diberi TT sangat beragam. Hal ini dapat dipengaruhi oleh kondisi individu sendiri sebagai (healee), kondisi terapis (healer), dan energi dari lingkungan. Sebagaimana dua responden ke-4 dan responden ke-16 telah mengalami respon fisiologis yang berbeda, dimana TT mampu meningkatkan tekanan darah penderita hipertensi (responden ke-16) yang sedang turun (drop) hingga tekanan darah mencapai kenaikan $20 \mathrm{mmHg}$ pada hari ke-2. TT juga mampu menurunkan tekanan darah penderita hipertensi yang sedang mengalami peningkatan tekanan darah cukup tinggi (responden ke-16) hingga tekanan darah mencapai penurunan $25 \mathrm{mmHg}$ pada hari ke2. 
Terapi TT yang dijalankan dengan benar akan memperbaiki dan menciptakan keseimbangan bioenergi individu baik melalui jalur saraf maupun hormonal, yang secara otomatis akan memberikan kekuatan pada fisiologi tubuh untuk berjalan lebih baik dibandingkan sebelum dilakukan penyeimbangan energi. Oleh sebab itu, TT sangat memungkinkan diterapkan sebagai salah satu intervensi keperawatan komplementer untuk meningkatkan kesehatan tubuh, khsusunya dalam meningkatkan stabilitas dan fungsi sistem kardiovaskuler penderita hipertensi yang salah satu indikatornya adalah tekanan darah. Sebuah sistematik review menunjukkan efektivitas TT untuk mengikutsertakan kembali "ketidakseimbangan medan energi" ke daftar diagnosis keperawatan. Akan tetapi perlu dilakukan tinjauan yang lebih sistematis dan juga dilakukan penelitian lanjutan dengan standar yang lebih baik untuk memberikan lebih banyak bukti tentang manfaat pemberian terapi energi (Cheraghi, Sadat, Hosseini, Gholami, \& Bagheri, 2017). Masih banyak penderita hipertensi di Indonesia yang belum melakukan kontrol, cek kesehatan, atau mencari pertolongan ke pusat layanan kesehatan (Huzaimah, 2020) terutama penduduk yang tinggal jauh dari kota dan kesulitan akses layanan kesehatan, bahkan masih banyak yang tidak mau melakukan pengobatan. Maka dari itu tenaga kesehatan utamanya perawat dapat mengawali terapi non-farmakologis ini (TT) untuk membantu individu yang masih belum memutuskan untuk berobat dalam menangani hipertensinya.

\section{SIMPULAN DAN SARAN \\ Simpulan}

Simpulan dari penelitian ini adalah therapeutic touch (TT) memberikan pengaruh penurunan tekanan darah sistolik dan tekanan darah diastolik pada hari diberikan intervensi (T1) dan hari berikutnya (T2), akan tetapi hasil statistik secara keseluruhan tidak signifikan kecuali pada perbandingan antara tekanan darah diastolik malam T0 dan tekanan darah diastolik malam T1. TT dapat menjadi pilihan intervensi keperawatan dalam memberikan asuhan keperawatan pada penderita hipertensi di area komunitas.

\section{Saran}

1. Bagi praktisi keperawatan dan mahasiswa keperawatan dapat mengikuti pelatihan Therapeutic Touch sebagai upaya meningkatkan kompetensi dan menerapkan terapi komplementer TT dalam pengobatan integratif dan holistik pada penderita hipertensi.

2. Bagi peneliti selanjutnya untuk meninjau secara lebih mendalam dan dengan jumlah sampel yang lebih besar untuk mengetahui efek TT terhadap variabel-variabel fisiologis lain pada penderita hipertensi maupun penyakit lain. Selanjutnya juga diperlukan metode yang lebih baik dengan menggunakan uji coba secara acak demi mendapatkan hasil penelitian yang lebih baik. Pengaruh kondisi terapis terhadap individu yang diterapi juga penting untuk diteliti mengingat intervensi TT sangat mengutamakan konsentrasi dan intuisi terapis (healer). Selanjutnya juga perlu diteliti biomarker yang paling utama sebagai dampak dari pemberian TT.

\section{UCAPAN TERIMA KASIH}

Penulis mengucapkan terima kasih kepada Lembaga Layanan Pendidikan Tinggi Wilayah VII, Kementerian Pendidikan dan Kebudayaan yang telahm memberi dukungan moral dan dana terhadap pelaksanaan kegiatan penelitian ini.

\section{DAFTAR PUSTAKA}

Astuti, D., \& Yulisetyaningrum, Y. (2016). PENGARUH TERAPI HEALING TOUCH TERHADAP PERUBAHAN TEKANAN DARAH PASIEN HIPERTENSI DI DESA TULAKAN DONOROJO JEPARA. Jurnal Ilmu Keperawatan Dan Kebidanan, 7(2). 
Bulette Coakley, A., \& Duffy, M. E. (2010). The effect of therapeutic touch on postoperative patients. Journal of Holistic Nursing, 28(3), 193-200.

Cai, F.-F., \& Zhang, H. (2015). Effect of therapeutic touch on agitated behavior in elderly patients with dementia: A review. International Journal of Nursing Sciences, 2(3), 324328.

Cheraghi, M. A., Sadat, A., Hosseini, S., Gholami, R., \& Bagheri, I. (2017). Therapeutic Touch efficacy : A Systematic Review, 5(4), 52-59.

Coakley, A. B., \& Hospital, M. G. (2015). The Effect of Therapeutic Touch on Postoperative Patients, (October). https://doi.org/10.1177/0898010110368861

Cox, C., \& Hayes, J. (1999). Physiologic and psychodynamic responses to the administration of therapeutic touch in critical care, 44(0), 87-92.

Cox, C. L., \& Hayes, J. A. (1997). Reducing anxiety: the employment of therapeutic touch as a nursing intervention. Complementary Therapies in Nursing and Midwifery, 3(6), 163167.

Fabbian, F., Smolensky, M. H., Tiseo, R., Pala, M., Manfredini, R., \& Portaluppi, F. (2013). Dipper and non-dipper blood pressure 24-hour patterns: circadian rhythm-dependent physiologic and pathophysiologic mechanisms. Chronobiology International, 30(1-2), $17-30$.

Foley, M. K. H., Anderson, J., Mallea, L., Morrison, K., \& Downey, M. (2016). Effects of Healing Touch on postsurgical adult outpatients. Journal of Holistic Nursing, 34(3), 271-279.

Gordon, A., Merenstein, J. H., D’Amico, F., \& Hudgens, D. (1998). The effects of therapeutic touch on patients with osteoarthritis of the knee. Journal of Family Practice, 47(4), 271-278.

Hanley, M. A., Coppa, D., \& Shields, D. (2017). A practice-based theory of healing through therapeutic touch: Advancing holistic nursing practice. Journal of Holistic Nursing, 35(4), 369-381.

Hikmah, E., Rustina, Y., \& Pujasari, H. (2011). Peningkatan Suhu Bayi Prematur Melalui Terapi Sentuhan. Jurnal Keperawatan Indonesia, 14(3), 179-184.

Huzaimah, N. (2020). BASELINE CHARACTERISTICS OF TREATED AND UNTREATED PEOPLE WITH HYPERTENSION. In Second Prosiding Conference on Research and Community Services (pp. 731-741). STKIP PGRI Jombang. Retrieved from https://ejournal.stkipjb.ac.id/index.php/CORCYS/article/view/1604

Jackson, E., Kelley, M., Mcneil, P., Meyer, E., Schlegel, L., \& Eaton, M. (2007). Does Therapeutic Touch Help Reduce Pain and Anxiety in Patients With Cancer?, 12(1).

Keller, E., \& Bzdek, V. M. (1986). Effects of therapeutic touch on tension headache pain. Nursing Research.

Kesehatan, K. (2018). HASIL UTAMA RISKESDAS 2018.

Matourypour, P., Vanaki, Z., Zare, Z., Mehrzad, V., Dehghan, M., \& Ranjbaran, M. (2016). Investigating the effect of therapeutic touch on the intensity of acute chemotherapyinduced vomiting in breast cancer women under chemotherapy. Iranian Journal of Nursing and Midwifery Research, 21(3), 255. 
Monroe, C. M. (2009). The effects of therapeutic touch on pain. Journal of Holistic Nursing, 27(2), 85-92.

Movaffaghi, Z. (2006). Effects of Therapeutic Touch on Blood Hemoglobin and Hematocrit Level, 41-48.

Ningsih, N. F. (2017). Pengaruh terapi sentuhan terhadap suhu tubuh pada bayi prematur. Jurnal Ners, 1(1).

O’Mathúna, D. P. (2000). Evidence-based practice and reviews of therapeutic touch. Journal of Nursing Scholarship, 32(3), 279-285.

O’Mathúna, D. P. (2016). Therapeutic touch for healing acute wounds. Cochrane Database of Systematic Reviews, (5).

Pujiati, A., Hartini, S., \& Purnomo, E. (2017). PENGARUH TERAPI SENTUAHAN TERHADAP PENURUNAN SUHU TUBUH PADA BAYI USIA 2-12 BULAN DI PUSKESMAS LEBDOSARI SEMARANG. Karya Ilmiah, 9.

Quinn, J. F. (1984). Energy Exchange : and Extension.

Rosa, L., Rosa, E., Sarner, L., \& Barrett, S. (1998). A Close Look at Therapeutic Touch, 279(13), 1005-1010.

Sayre-Adams, J., Wright, S. G., Biley, F. C., \& Richardson, M. (2001). The theory and practice of therapeutic touch. Elsevier Health Sciences.

Smith, D. W., \& Broida, J. P. (2007). Pandimensional field pattern changes in healers and healees: experiencing therapeutic touch. Journal of Holistic Nursing, 25(4), 217-225.

Turan, N. (2015). Yoğun bakım ünitesinde terapötik dokunmanın önemi.

Zaeimi, M., Ramazani-Badr, F., \& Bahrami, M. (2017). The effect of Therapeutic Touch on Physiological Variables of Mechanically Ventilated Patients in Intensive Care Units. Preventive Care in Nursing and Midwifery Journal, 6(4), 24-31. 